Article

\title{
Oxidative Stress, Induced by Sub-Lethal Doses of BDE 209, Promotes Energy Management and Cell Cycle Modulation in the Marine Fish Cell Line SAF-1
}

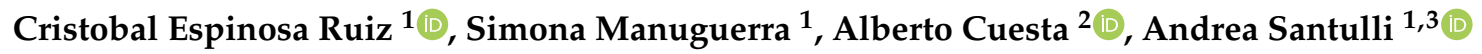 \\ and Concetta M. Messina ${ }^{1, *(D)}$ \\ 1 Laboratory of Marine biochemistry and ecotoxicology, Department of Earth and Marine Science DISTEM, \\ University of Palermo, Via Barlotta 4, 91100 Trapani, Italy; cristobal.espinosaruiz@unipa.it (C.E.R.); \\ simona.manuguerra@unipa.it (S.M.); andrea.santulli@unipa.it (A.S.) \\ 2 Fish Innate Immune System Group, Department of Cell Biology and Histology, Faculty of Biology, Campus \\ Regional de Excelencia Internacional "Campus Mare Nostrum”, University of Murcia, 30100 Murcia, Spain; \\ alcuesta@um.es \\ 3 Marine Biology Institute, Consorzio Universitario della Provincia di Trapani, Via Barlotta 4, \\ 91100 Trapani, Italy \\ * Correspondence: concetta.messina@unipa.it
}

Received: 2 January 2019; Accepted: 2 February 2019; Published: 6 February 2019

\begin{abstract}
The effects of sub-lethal doses of polybrominated diphenyl ether (PBDE)-209 in terms of toxicity, oxidative stress, and biomarkers were evaluated in the Sparus aurata fibroblast cell line (SAF-1). Vitality and oxidative stress status were studied after incubation with PBDE for $72 \mathrm{~h}$. Concomitantly, the quantification of proteins related to cell cycle and DNA repair (p53), cell proliferation (extracellular signal-regulated kinase 1 (ERK1)), energetic restriction (hypoxia-inducible factor 1 (HIF1)), and redox status (Nuclear factor erythroid 2-related factor 2 (NRF2)) was also determined after prolonged exposure (7-15 days) by immunoblotting. Our results demonstrated that rising concentrations of PBDEs exposure-induced oxidative stress, and that this event modulates different cell pathways related to cell cycle, cell signaling, and energetic balance in the long term, indicating the negative impact of sub-lethal dose exposure to cell homeostasis.
\end{abstract}

Keywords: PBDE-209; Sparus aurata fibroblast; oxidative stress; biomarkers

\section{Introduction}

Polybrominated diphenyl ethers (PBDEs) are a group of stable chemical compounds widely used in diverse polymers and plastics as flame retardants [1,2]. Among them, 2,2' $, 3,3^{\prime}, 4,4^{\prime}, 5,5^{\prime}, 6,6^{\prime}-$ decabromodiphenyl ether (BDE-209) is the principal component found in commercial mixtures of PBDEs [3,4]. Regrettably, due to its properties, PBDEs accumulate in aquatic environments where they are ubiquitous, toxic, and persistent [5-8]. In addition, under certain environmental conditions it has been suggested that BDE-209 can be transformed into lower-brominated PBDEs congeners by physics and biological processes [9].

BDE-209 and its congeners have been demonstrated to produce negative effects on human health [10-12] and the health of laboratory/wild animals [13-15]. In fact, BDE-209 has been shown to produce oxidative stress and toxicity [16], affecting the thyroid endocrine system in fish and mammals [17-20], while PBDEs congeners are able to impair behavior, growth, reproductive, hepatic, and renal functions as well as immune and endocrine systems in fish $[16,17,21-26]$.

It has been proposed that marine contaminants, contributing to the degradation of the nursery habitat and influencing the general welfare of fish have led to the decline of some wild marine 
fish populations [27] and to the alteration of the productivity of some marine fish stocks, due to the accumulation of pollutants [28-30]. For these reasons, the study of the effects and mechanisms determined by these toxicants in fish has attracted much attention. In this sense, the use of in vitro systems, represented by primary or permanent cell lines, or in vitro explants is considered more and more useful for studying the mechanisms of toxicology and represents a good alternative to in vivo trials with fish [31].

Different in vitro experiments have demonstrated that PBDEs have the ability to induce altered cell proliferation, as shown in the female reproductive system (human ovarian carcinoma cell line (OVCAR-3)) and normal ovarian (chinese hamster ovary cell line (CHO)) cells, mediated via phosphorylation of PKC $\alpha$ and ERK1/2 proteins [32], or induce the up-regulation of p53 and p23 in Neuro-2a cells [33]. In addition, toxicity, oxidative stress, and cell cycle arrest were described on spermatocytes from mice [34] and HepG2 cell lines treated with PBDEs [35]. In living organisms, PBDEs may be metabolized to more polar compounds-as shown experimentally in exposed mice and rats-that transform into hydroxylated, methoxylated, and/or conjugated metabolites $(\mathrm{OH}-, \mathrm{MeO}-$ and GS-PBDEs, respectively) via phase I and phase II metabolic enzymes [36,37].

In the case of fish, molecular mechanisms by which the PBDEs affect viability and cell cycle are still unknown, although oxidative stress has been suggested as the principal process involved in cell aggression. On the other hand, it is reasonable to think that the fact there is no toxicant effect does not mean the compounds are not producing cell damage. In fact, exposure to sub-lethal doses could promote other adverse effects after long-term exposure. Current knowledge about the sub-lethal effects of BDE-209 in aquatic organisms is still insufficient [17]. Because of this, the evaluation of biomarkers that could detect the negative effects of sub-lethal concentrations of PBDEs may be of great interest. In addition, as far as we know, very few papers have evaluated the effect of PBDEs using marine fish cell lines [38,39]. With the aim to clarify some of these aspects, we evaluated the effect of PBDEs in the Sparus aurata fibroblast cell line (SAF-1) model system.

Vitality and oxidative stress status were studied after incubation with PBDEs for a short time $(72 \mathrm{~h}$ ). Additionally, the quantification of proteins related to cell cycle (p53, a protein involved on cell cycle arrest and DNA repair), cell proliferation (extracellular signal-regulated kinase 1 (ERK1), a kinase involved on cell proliferation through complex signaling pathways), energetic balance (hypoxia-inducible factor 1 (HIF1), a protein complex regulated by oxygen availability, able to modulate glycolytic enzymes and ATP production), and oxidative stress (Nuclear factor erythroid 2-related factor 2 (NRF2), considered as an oxidative stress sensor that activates the antioxidant and detoxifying response) were determined after a prolonged exposure (7-15 days).

\section{Material and Methods}

\subsection{SAF-1 Cell Culture}

The established cell line SAF-1 (ECACC ${ }^{\circ} 00122301$ ), from fibroblast of Sparus aurata, was seeded in $25 \mathrm{~cm}^{2}$ plastic tissue culture flasks (Nunc, Darmstadt, Germany) cultured in L-15 Leibowitz medium (Sigma, Haverhill, UK), supplemented with 10\% fetal bovine serum (FBS, Sigma, UK), 2 mmol L ${ }^{-1}$ L-glutamine (Sigma, UK), 100 i.u. $\mathrm{mL}^{-1}$ penicillin (Sigma, UK), and $100 \mathrm{~g} \mathrm{~L}^{-1}$ streptomycin (Sigma, UK). Cells were grown at $25{ }^{\circ} \mathrm{C}$ in a humidified atmosphere ( $85 \%$ humidity).

Exponentially growing cells were detached from culture flasks by brief exposure to $0.25 \%$ of trypsin in PBS, pH 7.2-7.4, according to the standard trypsinization methods. The detached cells were collected by centrifugation $\left(11,200 \times g, 5 \mathrm{~min}, 25^{\circ} \mathrm{C}\right)$, and the cell vitality was determined by the trypan blue exclusion test.

\subsection{Cytotoxicity Assay on SAF-1 Cell Line}

Cytotoxicity assay was performed in five replicates. When SAF-1 cell lines were approximately $80 \%$ confluent, they were detached from flasks cultured with trypsin (as described before), and aliquots 
of $100 \mu \mathrm{L}$ containing 10,000 cell well $^{-1}$ were dispensed in 96-well tissue culture plates and incubated $\left(24 \mathrm{~h}, 25^{\circ} \mathrm{C}\right)$. This cell concentration was pre-determined in order to obtain satisfactory absorbance values in the cytotoxic assay, and to avoid cell over-growth. After that, the culture medium was replaced by $100 \mu \mathrm{L}$ well ${ }^{-1}$ of the PBDEs to be tested at the appropriate dilution.

The PBDE standard (100\% of purity) was provided by SPECTRA (Rome, Italy); stock solution of BDE-209 at a concentration of $25 \mathrm{mmol} \mathrm{L}{ }^{-1}$ was prepared by dissolving the powder compounds in dimethyl-sulfoxide (DMSO). Tested concentrations of BDE-209 ranged from 0.25 to $2 \mu \mathrm{mol} \mathrm{L}{ }^{-1}(0.25$, $0.5,0.75,1$, and 2). Cells were then incubated for 24,48 , and $72 \mathrm{~h}$ in three different plates at $25^{\circ} \mathrm{C}$. Control samples received the same volume of culture medium and DMSO $(0.1 \%)$, although the absence of the effects by the vehicle is well known $[40,41]$. After 24,48 , and $72 \mathrm{~h}$ at $25^{\circ} \mathrm{C}$, their vitality was determined using the tetrazolium salt (3-(4,5-dimethylthiazol-2-yl)-2,5-diphenyltetrazolium bromide) (MTT) assay.

The MTT assay is based on the reduction of the yellow soluble MTT (Sigma-Aldrich, Saint Louis, USA) into a blue, insoluble formazan product by the mitochondrial succinate dehydrogenase [42,43]. After incubation with the PDEs, SAF-1 cells were washed with phosphate buffer saline solution (PBS) and $200 \mu \mathrm{L}$ well ${ }^{-1}$ of MTT $\left(1 \mathrm{~g} \mathrm{~L}^{-1}\right)$ was added. After $4 \mathrm{~h}$ of incubation, cells were washed again and the formazan crystals solubilized with $100 \mu \mathrm{L}$ well ${ }^{-1}$ of DMSO. Plates were shacked (5 min, $100 \mathrm{rpm}$ ) in dark conditions, and the absorbance at $570 \mathrm{~nm}$ and $690 \mathrm{~nm}$ was determined in a microplate reader (Opsys MR ${ }^{\mathrm{TM}}$ Microplate Reader, DYNEX TECHNOLOGIES INC., Chantilly, VA, USA). After the individuation of the sub-lethal concentrations, the next experiments were done in order to assess molecular markers related to different biochemical patterns.

\subsection{Evaluation of Intracellular Reactive Oxygen Species (ROS)}

SAF-1 cells were incubated with different concentrations of BDE-209, as described above. After $72 \mathrm{~h}$ of treatment, intracellular ROS were analyzed on cell seeded in 96 microplate, using the dichlorodihydrofluorescein-diacetate (DCF-DA) method [44] with some modifications [41]. DCF-DA is oxidized to dichlorodihydrofluorescein (DCF) by ROS. Each well was exposed to $10 \mu \mathrm{L}$ of DCF-DA in HBSS ( $5 \mathrm{mg} \mathrm{L}^{-1}$ ), incubated for $5 \mathrm{~min}$ at $37^{\circ} \mathrm{C}$ to allow the oxidation of the DCF-DA, and successively read on a spectrofluorometer ( 485 exc-530 em, Varian Cary Eclipse, Mulgrave, Victoria, Australia). The results have been expressed as relative fluorescence/ $\mu \mathrm{g}$ of total proteins $\left(\mathrm{rf} \mu \mathrm{g} \mathrm{tp}^{-1}\right)$.

\subsubsection{Evaluation of Molecular Markers by Immunoblotting}

For the evaluation of molecular markers related to the different pathways of oxidative stress, cell cycle progression, apoptosis, and energy balance management, a long-term experiment lasting 15 days was carried out in flask, for each compound, at only one sub-lethal concentration $\left(1 \mu \mathrm{mol} \mathrm{L}{ }^{-1}\right)$. This dose was chosen as it corresponds to the range in which both the cell vitality and the ROS production changed, and could therefore return us information on the molecular patterns activated by the PBDE in the long term.

SAF- 1 cells $\left(40,000\right.$ cells $\left.\mathrm{cm}^{-2}\right)$ were incubated in a $25 \mathrm{~cm}^{2}$ flask (Nunc, Germany) and exposed to BDE-209 at $1 \mu \mathrm{mol} \mathrm{L}{ }^{-1}$. The sampling for immunoblotting analyses were done after 7 and 15 days. At each time of sampling, two replicates were realized. After the treatment, the cells were recovered by trypsinization and centrifugation, as previously described, incubated for $30 \mathrm{~min}$ on ice in lysis buffer (1:4) (1\% NP-40, $0.5 \%$ sodium deoxycholate, $0.1 \%$ sodium dodecyl sulfate (SDS), cocktail of protease inhibitors), and sonicated. Protein concentration was measured in total lysate, according to the method described by Lowry [45]. Experiments were carried out in duplicate.

\subsubsection{Immunoblotting}

Equivalent amounts of proteins $(20 \mu \mathrm{g})$ were loaded on pre-cast gel for SDS-polyacrylamide electrophoresis (SDS-PAGE), (Bio-Rad, Hercules, CA, USA) and blotted using a Trans Blot Turbo Transfer System (Bio-Rad, Hercules, CA, USA). The correct amount of protein loading was confirmed 
by red Ponceau staining. Filters were used for protein detection by primary antibodies (AbI) specifically for p53, extracellular signal-regulated kinase 1 (ERK1), phospho-AMP-activated protein kinase (AMPK), hypoxia-inducible factor (HIF), and nuclear factor (erythroid-derived 2)-like 2 (NRF2) (Sigma-Aldrich, Dorset, UK; Santa Cruz, CA, USA). In relation to the origin of the AbI, the appropriate secondary antibodies were used (anti-mouse or anti-rabbit, anti-goat secondary antibody conjugated with horseradish peroxidase) (GAR/M-HRP Bio-Rad, Hercules, CA, USA). The signals originated by immunoreaction were detected using enhanced chemo-luminescent (ECL) reagents (Bio-Rad). Images were obtained, photographed, and digitalized with Chemi Doc XRS (Bio-Rad, Hercules, CA, USA), and further analyzed with Image Lab software (Bio-Rad, Hercules, CA, USA). The results were expressed as fold increase of each treatment in relation to the control, representing the mean value of three separate experiments.

\subsection{Statistical Analysis}

Statistical differences among the groups were assessed by one-way ANOVA analyses, followed by the Bonferroni or Games Howell test, depending on the homogeneity of the variables. The normality of the variables was confirmed by the Shapiro-Wilk test, and homogeneity of variance by the Levene test. The significance level was $95 \%$ in all cases $(p<0.05)$. All the data were analyzed by the computer application SPSS for Windows ${ }^{\circledR}$ (version 20.0, SPSS Inc., Chicago, IL, USA).

\section{Results}

\subsection{Cytotoxicity Assay}

The effects of BDE 209 on the vitality of SAF-1 cells were investigated by MTTs. The results showed that only the dose $0.75 \mu \mathrm{mol} \mathrm{L}{ }^{-1}$ of BDE 209 at $24 \mathrm{~h}$ significantly altered the cell vitality, with respect to the control samples $(88.4 \pm 1.4 \%$ of vitality; $p=0.03$ ) (Figure $1 \mathrm{~A}-\mathrm{C}$ ).

\subsection{Evaluation of Intracellular ROS}

A significant production of ROS was induced after $72 \mathrm{~h}$ of incubation, with respect to the control $(p<0.05)$, by the higher concentration of BDE $209\left(2 \mu \mathrm{mol} \cdot \mathrm{L}^{-1}\right)$ samples (Figure 1D).

\subsection{Immunoblotting of Cell Cycle Biomarkers}

Western blot analysis was carried out on SAF-1 cells in order to evaluate the presence and levels of selected proteins in response to the treatment, with a selected sub-lethal concentration of BDE-209 $\left(1 \mu \mathrm{mol} \mathrm{L}{ }^{-1}\right)$ for a long time (7 and 15 days). The results are illustrated in Figure 1E. SAF- 1 cells treated with BDE-209 showed a significant decrease $(p<0.05)$ in the levels of p53 at 7 days, but not at 15 days, with respect to the control. Regarding the marker of cell proliferation, levels of ERK1 significantly decreased $(p<0.05)$ with respect to the control at 7 days, but not at 15 days. The selected markers of energetic balance (AMPK and HIF) significantly decreased in cells treated with BDE-209 at 7 and 15 days $(p<0.05)$. Finally, the level of the marker related to the oxidative stress, NRF-2, significantly increased, with respect to the control $(p<0.05)$. 

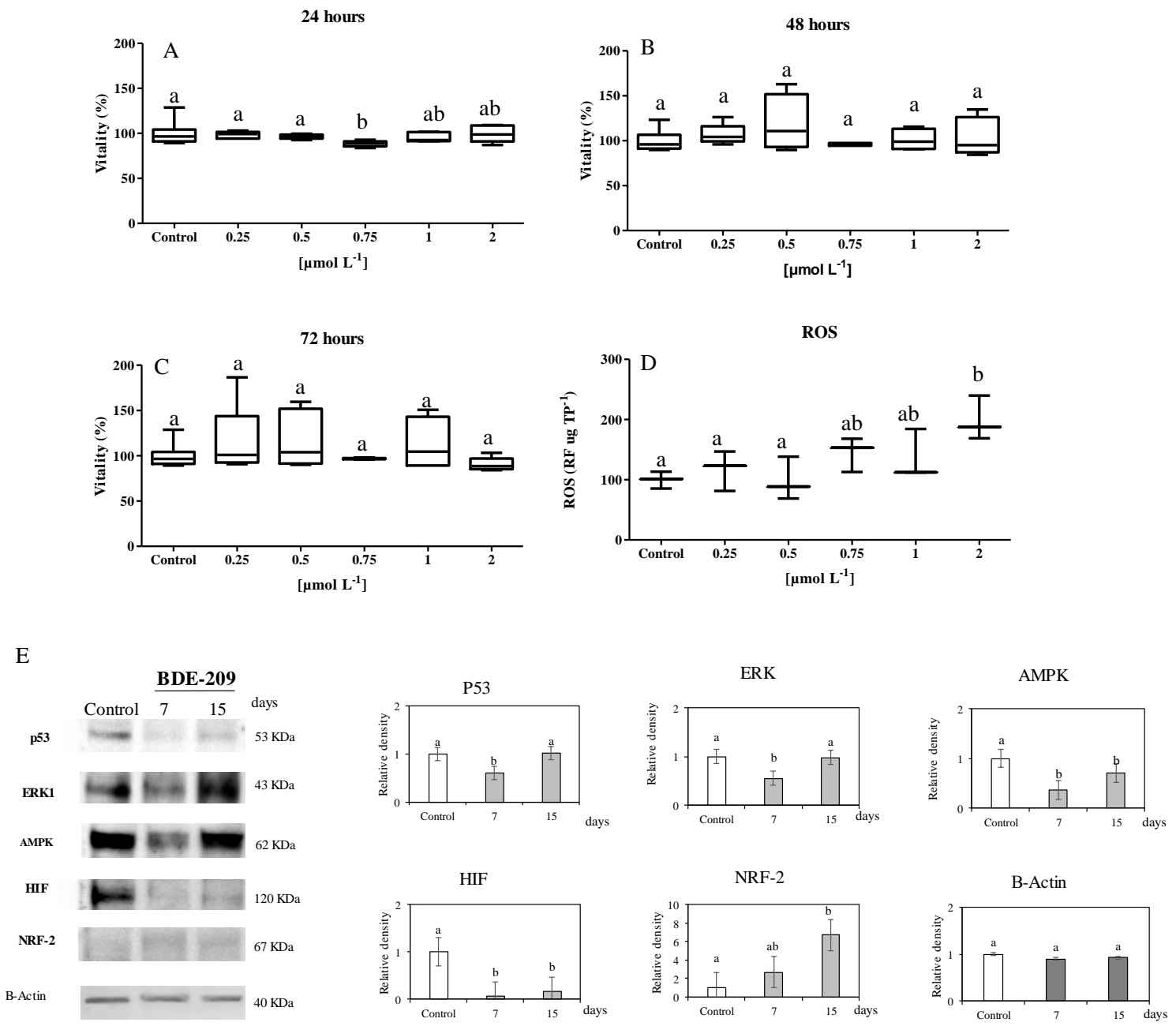

Figure 1. (A-C) Cytotoxicity of SAF-1 cells (fibroblast from Sparus aurata) exposed to different concentrations of polybrominated diphenyl ether-209 (BDE 209) $\left(0.25-2 \mu \mathrm{mol} \mathrm{L}^{-1}\right)$ for 24,48 , and $72 \mathrm{~h}$. (D) Reactive oxygen species (ROS) production, expressed as relative fluorescence $\times \mu \mathrm{g}$ total proteins $^{-1}$, in SAF-1 cells exposed to different concentrations of BDE $209(0.25-2 \mu \mathrm{mol} \mathrm{L}-1)$ for $72 \mathrm{~h}$. (E) Immunoblotting of some proteins related to cell cycle (p53), proliferation (ERK), energetic balance (HIF, AMPK), and oxidative stress (NRF-2) in SAF-1 cells control: cell not exposed to the compound. Immunoblotting of actin protein is used as internal control for total proteins. Bars represent the mean \pm SEM $(n=6)$. Statistically significant differences vs. the control (ANOVA; $p \leq 0.05$ ) are denoted using different letters.

\section{Discussion}

The aim of the present study was to use the SAF-1 cell line as an in vitro model system to investigate the molecular mechanisms involved in cell cycle, cell metabolism, and oxidative stress produced by BDE-209, one of the most abundant PBDEs present in the environment and in wildlife [46-48].

Overall, PBDEs failed to affect SAF-1 cells after 24, 48, or $72 \mathrm{~h}$ of exposure. Although other polybrominated compounds-such as BDE-47 or BDE-99-have been shown to present toxicity in other models at the same or lower concentrations than used in our experiment [39], it has been demonstrated that low bromine BDE congeners (such as BDE-99 and 47) have been proved to be more toxic than higher bromine BDE congeners (as BDE-209) [49]. In fact, our results showed an increased trend in cell vitality with lower doses at 48 and $72 \mathrm{~h}$, which agrees with previous research on different cell lines: in the ZFL cell line (liver from zebra fish), it was demonstrated that BDE-209 did not affect cell vitality, even at $96 \mathrm{~h}$, at doses of up to $25 \mu \mathrm{mol} \mathrm{L}{ }^{-1}$ [39]; on PC12 cells, concentrations ranging from 6.25 to $12.5 \mu \mathrm{mol} \mathrm{L}^{-1}$ (higher than the concentrations used in the present experiment) did not influence 
the vitality of cells [50]; also, on fibroblast cells obtained from Stenella attenuate, BDE-209 concentrations ranging from $260 \mathrm{nmol} \mathrm{L}^{-1}$ to $10 \mu \mathrm{mol} \mathrm{L}{ }^{-1}$ did not determine a reduction in cell vitality [51].

Surprisingly, the vitality of SAF-1 cells was significantly decreased at $24 \mathrm{~h}$ with the $0.75 \mu \mathrm{mol} \cdot \mathrm{L}^{-1}$, while higher doses failed to decrease cell vitality in the same time. There has been little discussion about the fact that many endocrine-disrupting chemicals do not generate the standard trend of dose-response curves seen for other types of compounds [52], showing that lower concentrations of the contaminant could produce higher effects. In fact, it has been reported that bisphenol A [53], p-nonyphenol [54], and atrazine [55] produced this kind of response on different models. This could be a possible explanation for our vitality results.

Additionally, after PBDEs exposure, SAF-1 cells showed an increase of the intracellular ROS levels, in a dose-response manner (Figure 1D-F). Our results are in accord with other works on HepG2 [36,56] or in Neuro-2a [57] that reported that the PBDEs exposure induces oxidative stress. In addition to in vitro studies, an in vivo experiment showed that BDE-209 increased lipid peroxidation on germ cells from mice and decreased their antioxidant defenses [58].

However, the exact mechanisms by which these contaminants affect cell homeostasis, response to stress, metabolism, and cell cycle remain unclear. With the aim to elucidate this issue, the levels of different proteins related to the cell cycle, cell proliferation, energetic balance, and oxidative stress were analyzed on SAF-1 cells after exposure to a sub-lethal concentration of BDE-209 $\left(1 \mu \mathrm{mol} \mathrm{L}{ }^{-1}\right)$ for 7 and 15 days.

After 7 and 15 days of BDE-209 exposure, p53 levels were significantly affected by PBDE treatment. p53 plays an important role in cell cycle regulation [59], increasing its levels in situations that can induce DNA damage, and assisting its reparation by promoting cell cycle arrest. For this reason, p53 is considered a biomarker relating to cell protection [60]. Surprisingly, BDE-209 produced a significant decrease of p53 levels after 7 days of treatment. This observation contrasts with other in vitro works that reported an increase of p53 expression in Neuro-2 cells exposed to BDE, BDE-47 and 99 [34], or in zebra fish embryos after exposure to a mix of PBDEs [61], as well as the increase of p53 expression in SH-SY5Y cells after BDE-47 treatment [62]. Nevertheless, the complexity of these pathways complicates the interpretation of these results, as is true that the decrease of p53 observed in our experiment could avoid DNA reparation and cell cycle arrest that p53 leads under stress conditions, increasing the susceptibility to mutagenesis and cell cycle disruption.

ERK1 plays a main role in cell activation, promoting cell proliferation and differentiation [63-65]. Our results revealed that ERK1 levels were significantly decreased at 7 days, which contrasts with other reports that showed PBDEs exposure significantly increased the levels of ERK1/2 in OVCAR-3 cells [66], cerebellar granule neurons [67], and HeLa cells [33]. However, the decrease of ERK1 levels could exacerbate the damage produced by BDE-209, as it has been suggested with HepG2 exposed to 1,2-dichloroethane [68]. Since ERK1/2 activation plays a protective role towards oxidative stress and others cell insults, its inhibition may result in a reduction of protective effects [69], however further research is needed to clarify this issue.

The enzymatic complex AMPK is activated by the increase of AMP/ATP ratio, and is therefore considered an indicator of cell energy levels [70]. Our results revealed that AMPK levels significantly decreased at both 7, and 15 days. In this sense, we hypothesized that a decrease of ATP levels could be due to a prolonged activity of antioxidant enzymes and phase I/II enzymes. The increase of intracellular ROS observed in our experiment seems to support our hypothesis. However, our results contrast with other reports that showed a decrease on ATP levels after BDE-47 or 99 exposure on isolated mitochondria from rat liver [71], correlating the PBDEs exposure with an increase of AMPK levels [70]. Nevertheless, a decrease of AMPK levels may be associated with changes in metabolism (low levels of ATP which leads anaerobic conditions), as described in cancer development [72] and in various types of cancer [73]. In fact, due to the fact that AMPK regulates energy levels, reinforces metabolic checkpoints, and inhibits cell growth [73], this protein is considered a tumor suppressor-therefore, the decrease of AMPK levels observed in our experiment could entail cancer promotion, although the mechanisms implicated in PBDEs effects are still unclear. 
In our experiment, levels of HIF-1 showed a significant decrease after PBDEs exposure, which contrasts with some data reported by other authors that showed HIF-1 is increased under oxidative stress situations [74-76]. During a situation of oxidative stress, HIF-1 is normally activated [74,77], being translocated to the nucleus, and activates hypoxia-responsive elements (HRE) through the ARNT (aryl hydrocarbon receptor nuclear translocator). In this sense, it has been reported that HIF-1 activity could be influenced by the aryl hydrocarbon receptor (AhR) [78], which is activated by xenobiotics (such as polybrominated dibenzo-p-dioxins and dibenzofurans (PBDD/Fs)) and interacts with ARNT. Interestingly, some studies on the effects of PBDD/Fs on health suggested that this compound can produce a similar toxicity profile to its halogenated homologs [79], and that it can be hydroxylated under determinate conditions [80]. For this reason, AhR agonists can downregulate the HIF-1 pathway due to competition for ARNT [81-83]. This could be a plausible explanation of our results, although more research is needed to better understand this aspect.

NRF-2 plays protective roles, leading the expression of a wide range of antioxidants and phase II detoxification genes [84]. In our experiment, the levels of NRF-2 increased, suggesting that PBDEs exposure was able to activate the NRF-2 response in SAF-1 cells, probably via oxidative stress. Our observations agree with other works that reported the upregulation of NRF-2 via oxidative stress after PBDEs exposure, both in vivo [85] and in vitro [57,86].

\section{Conclusions}

Our results show that increased doses of PBDE-209 concentrations produced-in our model system-oxidative stress at short-term exposure. In addition, several pathways related to cell cycle, cell signaling, energy balance, and oxidative stress are influenced by long-term exposure to sub-lethal doses of the compound. Overall, our results suggest that the cellular response to low doses of PBDEs could be attenuated after long-term exposure by several mechanisms, such as ARNT competition or decreased energy levels. Some biomarkers indicate that exposure to PBDE-209 could decrease their protective effect, promoting cellular damage mainly through oxidative stress. This situation, together with anaerobic metabolism, could promote cellular transformation. Further studies are needed to ascertain the potential impact of different PBDEs on fish biology, and in this context, the use of in vitro models can represent a good alternative to understand the molecular mechanisms involved.

Author Contributions: Conceptualization and Methodology, C.M.M.; Formal Analysis, C.E.R., S.M.; Investigation C.E.R.; Resources, C.M.M., A.S., and A.C.; Writing-Original Draft Preparation, C.E.R.; Writing-Review and Editing, C.M.M., C.E.R.; Supervision, C.M.M., AS.; Project Administration, C.M.M.; Funding Acquisition, C.M.M., A.S.

Funding: This research received no external funding.

Acknowledgments: This work was supported by the project: “Centro Internazionale di Studi Avanzati su Ambiente, ecosistema e Salute umana-CISAS", funded by CIPE-MIUR-CUP B62F15001070005.

Conflicts of Interest: The authors declare no conflict of interest.

\section{Abbreviations}

$\begin{array}{ll}\text { AhR } & \text { Aryl hydrocarbon receptor } \\ \text { AMPK } & \text { Adenosine 5'-monophosphate-activated protein kinase } \\ \text { AREs } & \text { Antioxidant response elements } \\ \text { ARNT } & \text { Aryl hydrocarbon receptor nuclear translocator } \\ \text { ERK-1 } & \text { Extracellular signal-regulated kinase 1 } \\ \text { HIF-1 } & \text { Hypoxia inducible factor 1 } \\ \text { NRF-2 } & \text { Nuclear factor (erythroid-derived 2)-like 2 } \\ \text { PBDEs } & \text { Polybrominated diphenyl ethers } \\ \text { PBDD/Fs } & \text { Polybrominated dibenzo-p-dioxins and dibenzofurans } \\ \text { ROS } & \text { Reactive oxygen species }\end{array}$




\section{References}

1. Teuten, E.L.; Saquing, J.M.; Knappe, D.R.U.; Barlaz, M.A.; Jonsson, S.; Björn, A.; Rowland, S.J.; Thompson, R.C.; Galloway, T.S.; Yamashita, R.; et al. Transport and release of chemicals from plastics to the environment and to wildlife. Philos. Trans. R. Soc. Lond. B Biol. Sci. 2009, 364, 2027-2045. [CrossRef] [PubMed]

2. Reynier, A.; Dole, P.; Humbel, S.; Feigenbaum, A. Diffusion coefficients of additives in polymers. I. Correlation with geometric parameters. J. Appl. Polym. Sci. 2001, 82, 2422-2433. [CrossRef]

3. Zou, M.-Y.; Ran, Y.; Gong, J.; Mai, B.-X.; Zeng, E. Polybrominated diphenyl ethers in watershed soils of the Pearl river delta, China: Occurrence, inventory, and fate. Environ. Sci. Technol. 2007, 41, 8262-8267. [CrossRef] [PubMed]

4. Han, Z.; Li, Y.; Zhang, S.; Song, N.; Xu, H.; Dang, Y.; Liu, C.; Giesy, J.P.; Yu, H. Prenatal transfer of decabromodiphenyl ether (BDE-209) results in disruption of the thyroid system and developmental toxicity in zebrafish offspring. Aquat. Toxicol. 2017, 190, 46-52. [CrossRef] [PubMed]

5. Hong, S.H.; Kannan, N.; Jin, Y.; Won, J.H.; Han, G.M.; Shim, W.J. Temporal trend, spatial distribution, and terrestrial sources of PBDEs and PCBs in Masan Bay, Korea. Mar. Pollut. Bull. 2010, 60, 1836-1841. [CrossRef] [PubMed]

6. Horri, K.; Alfonso, S.; Cousin, X.; Munshy, C.; Loizeau, V.; Aroua, S.; Bégout, M.-L.; Ernande, B. Fish life-history traits are affected after chronic dietary exposure to an environmentally realistic marine mixture of PCBs and PBDEs. Sci. Total Environ. 2018, 610-611, 531-545. [CrossRef] [PubMed]

7. Hu, G.; Xu, Z.; Dai, J.; Mai, B.; Cao, H.; Wang, J.; Shi, Z.; Xu, M. Distribution of polybrominated diphenyl ethers and decabromodiphenylethane in surface sediments from Fuhe River and Baiyangdian Lake, North China. J. Environ. Sci. (China) 2010, 22, 1833-1839. Available online: http://www.ncbi.nlm.nih.gov/ pubmed/21462698 (accessed on 11 December 2018). [CrossRef]

8. Kim, G.B.; Stapleton, H.M. PBDEs, methoxylated PBDEs and HBCDs in Japanese common squid (Todarodes pacificus) from Korean offshore waters. Mar. Pollut. Bull. 2010, 60, 935-940. [CrossRef]

9. Stapleton, H.M.; Brazil, B.; Holbrook, R.D.; Mitchelmore, C.L.; Benedict, R.; Konstantinov, A.; Potter, D. In vivo and in vitro debromination of decabromodiphenyl dther (BDE 209) by juvenile rainbow trout and common carp. Environ. Sci. Technol. 2006, 40, 4653-4658. [CrossRef]

10. Abdelouahab, N.; AinMelk, Y.; Takser, L. Polybrominated diphenyl ethers and sperm quality. Reprod. Toxicol. 2011, 31, 546-550. [CrossRef]

11. Main, K.M.; Kiviranta, H.; Virtanen, H.E.; Sundqvist, E.; Tuomisto, J.T.; Tuomisto, J.; Vartiainen, T.; Skakkabaek, N.E.; Toppari, J. Flame retardants in placenta and breast milk and ryptorchidism in newborn Boys. Environ. Health Perspect. 2007, 115, 1519-1526. [CrossRef] [PubMed]

12. McDonald, T.A. Polybrominated diphenylether levels among United States residents: Daily intake and risk of harm to the developing brain and reproductive organs. Integr. Environ. Assess. Manag. 2005, 1, 343-354. [CrossRef] [PubMed]

13. Gilchrist, T.T.; Letcher, R.J.; Thomas, P.; Fernie, K.J. Polybrominated diphenyl ethers and multiple stressors influence the reproduction of free-ranging tree swallows (Tachycineta bicolor) nesting at wastewater treatment plants. Sci. Total Environ. 2014, 472, 63-71. [CrossRef] [PubMed]

14. Kuriyama, S.N.; Talsness, C.E.; Grote, K.; Chahoud, I. Developmental exposure to low-dose PBDE-99: Effects on male fertility and neurobehavior in rat offspring. Environ. Health Perspect. 2004, 113, 149-154. [CrossRef] [PubMed]

15. Stoker, T.E.; Laws, S.C.; Crofton, K.M.; Hedge, J.M.; Ferrell, J.M.; Cooper, R.L. Assessment of DE-71, a Commercial polybrominated diphenyl ether (PBDE) mixture, in the EDSP male and female pubertal protocols. Toxicol. Sci. 2004, 78, 144-155. [CrossRef] [PubMed]

16. Yu, L.; Han, Z.; Liu, C. A review on the effects of PBDEs on thyroid and reproduction systems in fish. Gen. Comp. Endocrinol. 2015, 219, 64-73. [CrossRef] [PubMed]

17. Xie, Z.; Lu, G.; Qi, P. Effects of BDE-209 and its mixtures with BDE-47 and BDE-99 on multiple biomarkers in Carassius auratus. Environ. Toxicol. Pharmacol. 2014, 38, 554-561. [CrossRef]

18. Lee, E.; Kim, T.H.; Choi, J.S.; Nabanata, P.; Kim, N.Y.; Ahn, M.Y.; Jung, K.K.; Kang, I.H.; Kim, S.H.; Kang, T.S.; et al. Evaluation of liver and thyroid toxicity in Sprague-Dawley rats after exposure to polybrominated diphenyl ether BDE-209. J. Toxicol. Sci. 2010, 35, 535-545. [CrossRef] 
19. Chen, Q.; Yu, L.; Yang, L.; Zhou, B. Bioconcentration and metabolism of decabromodiphenyl ether (BDE-209) result in thyroid endocrine disruption in zebrafish larvae. Aquat. Toxicol. 2012, 110-111, 141-148. [CrossRef]

20. Noyes, P.D.; Lema, S.C.; Macaulay, L.J.; Douglas, N.K.; Stapleton, H.M. Low level exposure to the flame retardant BDE-209 reduces thyroid hormone levels and disrupts thyroid signaling in fathead minnows. Environ. Sci. Technol. 2013, 47, 10012-10021. [CrossRef]

21. Berg, V.; Lyche, J.L.; Karlsson, C.; Stavik, B.; Nourizadeh-Lillabachi, R.; Hårdnes, N.; Skaare, J.U.; Alestrøm, P.; Lie, E.; Ropstad, E. Accumulation and effects of natural mixtures of persistent organic pollutants (POP) in zebrafish after two generations of exposure. J. Toxicol. Environ. Health Part A 2011, 74, 407-423. [CrossRef] [PubMed]

22. Daouk, T.; Larcher, T.; Roupsard, F.; Lyphout, L.; Rigaud, C.; Ledevin, M.; Loizeau, V.; Cousin, X. Long-term food-exposure of zebrafish to PCB mixtures mimicking some environmental situations induces ovary pathology and impairs reproduction ability. Aquat. Toxicol. 2011, 105, 270-278. [CrossRef] [PubMed]

23. Han, X.B.; Lei, E.N.Y.; Lam, M.H.W.; Wu, R.S.S. A whole life cycle assessment on effects of waterborne PBDEs on gene expression profile along the brain-pituitary-gonad axis and in the liver of zebrafish. Mar. Pollut. Bull. 2011, 63, 160-165. [CrossRef] [PubMed]

24. Lyche, J.L.; Nourizadeh-Lillabadi, R.; Karlsson, C. Natural mixtures of POPs affected body weight gain and induced transcription of genes involved in weight regulation and insulin signaling. Aquat. Toxicol. 2011, 102, 197-204. [CrossRef] [PubMed]

25. Péan, S.; Daouk, T.; Vignet, C.; Lyphout, L.; Leguay, D.; Loizeau, V.; Bégout, M.-L.; Cousin, X. Long-term dietary-exposure to non-coplanar PCBs induces behavioral disruptions in adult zebrafish and their offspring. Neurotoxicol. Teratol. 2013, 39, 45-56. [CrossRef] [PubMed]

26. Han, X.B.; Yuen, K.W.Y.; Wu, R.S.S. Polybrominated diphenyl ethers affect the reproduction and development, and alter the sex ratio of zebrafish (Danio rerio). Environ. Pollut. 2013, 182, 120-126. [CrossRef] [PubMed]

27. Hamilton, P.B.; Cowx, I.G.; Oleksiak, M.F.; Griffiths, A.M.; Grahn, M.; Stevens, J.R.; Carvahlo, G.R.; Nicol, E.; Tyler, C.R. Population-level consequences for wild fish exposed to sublethal concentrations of chemicals-A critical review. Fish Fish. 2016, 17, 545-566. [CrossRef]

28. Gilliers, C.; Claireaux, G.; Galois, R.; Loizeau, V.; Le Pape, O. Influence of hydrocarbons exposure on survival, growth and condition of juvenile flatfish: A mesocosm experiment. J. Life Sci. 2003, 4, 113-122. [CrossRef]

29. Riou, P.; Le Pape, O.; Rogers, S.I. Relative contributions of different sole and plaice nurseries to the adult population in the Eastern Channel: Application of a combined method using generalized linear models and a geographic information system. Aquat. Living Resour. 2001, 14, 125-135. [CrossRef]

30. Rochette, S.; Rivot, E.; Morin, J.; Mackinson, S.; Riou, P.; Le Pape, O. Effect of nursery habitat degradation on flatfish population: Application to Solea solea in the Eastern Channel (Western Europe). J. Sea Res. 2010, 64, 34-44. [CrossRef]

31. Morcillo, P.; Cordero, H.; Meseguer, J.; Esteban, M.A.; Cuesta, A. In vitro immunotoxicological effects of heavy metals on European sea bass (Dicentrarchus labrax L.) head-kidney leucocytes. Fish Shellfish Immunol. 2015, 47, 245-254. [CrossRef] [PubMed]

32. Li, Z.H.; Liu, X.Y.; Wang, N.; Chen, J.-S.; Chen, Y.-H.; Huag, J.-T.; Su, C.-H.; Xie, F.; Yu, B.; Chen, D.-J. Effects of decabrominated diphenyl ether (PBDE-209) in regulation of growth and apoptosis of breast, ovarian, and cervical cancer cells. Environ. Health Perspect. 2012, 120, 541-546. [CrossRef] [PubMed]

33. Chen, H.; Tang, X.; Zhou, B.; Zhou, Z.; Xu, N.; Wang, Y. BDE-47 and BDE-209 inhibit proliferation of Neuro-2a cells via inducing G1-phase arrest. Environ. Toxicol. Pharmacol. 2017, 50, 76-82. [CrossRef] [PubMed]

34. Huang, S.; Wang, J.; Cui, Y. 2,2' $4,4^{\prime}$-Tetrabromodiphenyl ether injures cell viability and mitochondrial function of mouse spermatocytes by decreasing mitochondrial proteins Atp5b and Uqcrc1. Environ. Toxicol Pharmacol. 2016, 46, 301-310. [CrossRef] [PubMed]

35. An, J.; Li, S.; Zhong, Y.; Wang, Y.; Zhen, K.; Zhang, X.; Wang, Y.; Wu, M.; Yu, Z.; Sheng, G.; et al. The cytotoxic effects of synthetic 6-hydroxylated and 6-methoxylated polybrominated diphenyl ether 47 (BDE47). Environ. Toxicol. 2011, 26, 591-599. [CrossRef] [PubMed]

36. Malmberg, T.; Athanasiadou, M.; Marsh, G.; Brandt, I.; Bergman, Å. Identification of hydroxylated polybrominated diphenyl ether metabolites in blood plasma from polybrominated diphenyl ether exposed rats. Environ. Sci. Technol. 2005, 39, 5342-5348. [CrossRef] [PubMed] 
37. Qiu, X.; Mercado-Feliciano, M.; Bigsby, R.M.; Hites, R.A. Measurement of polybrominated diphenyl ethers and metabolites in mouse plasma after exposure to a commercial pentabromodiphenyl ether mixture. Environ. Health Perspect. 2007, 115, 1052-1058. [CrossRef]

38. Browne, E.P.; Stapleton, H.M.; Kelly, S.M.; Tilton, S.C.; Gallagher, E.P. In vitro hepatic metabolism of 2,2',4,4',5-pentabromodiphenyl ether (BDE 99) in Chinook Salmon (Onchorhynchus tshawytscha). Aquat. Toxicol. 2009, 92, 281-287. [CrossRef]

39. Yang, J.; Chan, K.M. Evaluation of the toxic effects of brominated compounds (BDE-47, 99, 209, TBBPA) and bisphenol a (BPA) using a zebrafish liver cell line, ZFL. Aquat Toxicol. 2015, 159, 138-147. [CrossRef]

40. Abbes, M.; Baati, H.; Guermazi, S.; Messina, C.; Santulli, A.; Gharsallah, N.; Ammar, E. Biological properties of carotenoids extracted from Halobacterium halobium isolated from a Tunisian solar saltern. BMC Complement. Altern. Med. 2013, 13, 255. [CrossRef]

41. Messina, C.M.; Pizzo, F.; Santulli, A.; Bušelić, I.; Boban, M.; Orhanović, S.; Mladineo, I. Anisakis pegreffii (Nematoda: Anisakidae) products modulate oxidative stress and apoptosis-related biomarkers in human cell lines. Parasit. Vectors 2016, 9, 607. [CrossRef]

42. Berridge, M.V.; Tan, A.S. Characterization of the cellular reduction of 3-(4,5-dimethylthiazol-2-yl)-2,5diphenyltetrazolium bromide (MTT): Subcellular localization, substrate dependence, and involvement of mitochondrial electron transport in MTT reduction. Arch. Biochem. Biophys. 1993, 303, 474-482. [CrossRef]

43. Denizot, F.; Lang, R. Rapid colorimetric assay for cell growth and survival: Modifications to the tetrazolium dye procedure giving improved sensitivity and reliability. J. Immunol. Methods 1986, 89, 271-277. [CrossRef]

44. Kang, K.A.; Lee, K.H.; Chae, S.; Zhang, R.; Jung, M.S.; Kim, S.Y.; Kim, H.S.; Kim, D.H.; Hyun, J.W. Cytoprotective effect of tectorigenin, a metabolite formed by transformation of tectoridin by intestinal microflora, on oxidative stress induced by hydrogen peroxide. Eur. J. Pharmacol. 2005, 519, 16-23. [CrossRef] [PubMed]

45. Lowry, O.H.; Rosebrough, N.J.; Farr, A.L.; Randall, R.J. Protein measurement with the Folin phenol reagent. J. Biol. Chem. 1951, 193, 265-275. [PubMed]

46. Leung, A.; Cai, Z.W.; Wong, M.H. Environmental contamination from electronic waste recycling at Guiyu, southeast China. J. Mater. Cycles Waste Manag. 2006, 8, 21-33. [CrossRef]

47. Bi, X.; Thomas, G.O.; Kevin, J.; Weiyue, Q.; Guoying, S.; Martin, F.L.; Jiamo, F. Exposure of electronics dismantling workers to polybrominated diphenyl ethers, polychlorinated biphenyls, and organochlorine pesticides in South China. Environ. Sci. Technol. 2007, 41, 5647-5653. [CrossRef]

48. Yang, J.; Zhu, J.; Chan, K.M. BDE-99, but not BDE-47, is a transient aryl hydrocarbon receptor agonist in zebrafish liver cells. Toxicol. Appl. Pharmacol. 2016, 305, 203-215. [CrossRef]

49. Birnbaum, L.S.; Staskal, D.F. Brominated flame retardants: Cause for concern? Environ. Health Perspect. 2004, 112, 9-17. [CrossRef]

50. Liu, Q.; Wang, K.; Shao, J.; Li, C.; Li, Y.; Li, S.; Liu, X.; Han, L. Role of taurine in BDE 209-induced oxidative stress in PC12 cells. Adv. Exp. Med. Biol. 2017, 975, 897-906. [CrossRef]

51. Rajput, I.R.; Xiao, Z.; Yajing, S.; Yaqoob, S.; Sanganyado, E.; Ying, H.; Fei, Y.; Liu, W. Establishment of pantropic spotted dolphin (Stenella attenuata) fibroblast cell line and potential influence of polybrominated diphenyl ethers (PBDEs) on cytokines response. Aquat. Toxicol. 2018, 203, 1-9. [CrossRef] [PubMed]

52. Fagin, D. The learning curve. Nature 2012, 490, 5-8. [CrossRef] [PubMed]

53. Jenkins, S.; Wang, J.; Eltoum, I.; Desmond, R.; Lamartiniere, C.A. Chronic oral exposure to bisphenol A results in a nonmonotonic dose response in mammary carcinogenesis and metastasis in MMTV-erbB2 mice. Environ. Health Perspect. 2011, 119, 1604-1609. [CrossRef] [PubMed]

54. Bulayeva, N.N.; Watson, C.S. Xenoestrogen-induced ERK-1 and ERK-2 activation via multiple membrane-initiated signaling pathways. Environ. Health Perspect. 2004, 112, 1481-1487. [CrossRef] [PubMed]

55. Hayes, T.B.; Collins, A.; Lee, M.; Mendoza, M.; Noriega, N.; Stuart, A.A.; Vonk, A. Hermaphroditic, demasculinized frogs after exposure to the herbicide atrazine at low ecologically relevant doses. Proc. Natl. Acad. Sci. USA 2002, 99, 5476-5480. [CrossRef] [PubMed]

56. Hu, X.Z.; Xu, Y.; Hu, D.C.; Hui, Y.; Yang, F.X. Apoptosis induction on human hepatoma cells Hep G2 of decabrominated diphenyl ether (PBDE-209). Toxicol. Lett. 2007, 171, 19-28. [CrossRef] [PubMed]

57. Chen, H.; Tang, X.; Zhou, B.; Zhou, Z.; Xu, N.; Wang, Y. A ROS-mediated mitochondrial pathway and $\mathrm{Nrf} 2$ pathway activation are involved in BDE-47 induced apoptosis in Neuro-2a cells. Chemosphere 2017, 84, 679-686. [CrossRef] 
58. Sarkar, D.; Singh, S.K. Maternal exposure to polybrominated diphenyl ether (BDE-209) during lactation affects germ cell survival with altered testicular glucose homeostasis and oxidative status through down-regulation of Cx43 and p27Kip1 in prepubertal mice offspring. Toxicology 2017, 386, 103-119. [CrossRef]

59. Yee, K.S.; Vousden, K.H. Complicating the complexity of p53. Carcinogenesis 2005, 26, 1317-1322. [CrossRef]

60. Zhang, W.; Liu, N.; Wang, X.; Jin, X.; Du, H.; Peng, G.; Xue, J. Benzo(a)pyrene-7,8-diol-9,10-epoxide induced p53-independent necrosis via the mitochondria-associated pathway involving Bax and Bak activation. Hum. Exp. Toxicol. 2015, 34, 179-190. [CrossRef]

61. Lyche, J.L.; Grześ, I.M.; Karlsson, C.; Nourizadeh-Lillabadi, R.; Aleström, P.; Ropstad, E. Parental exposure to natural mixtures of persistent organic pollutants (POP) induced changes in transcription of apoptosis-related genes in offspring zebrafish embryos. J. Toxicol. Environ. Health Part A 2016, 79, 602-611. [CrossRef] [PubMed]

62. Zhang, S.; Kuang, G.; Zhao, G.; Wu, X.; Zhang, C.; Lei, R.; Xia, T.; Chen, J.; Wang, Z.; Ma, R.; et al. Involvement of the mitochondrial p53 pathway in PBDE-47-induced SH-SY5Y cells apoptosis and its underlying activation mechanism. Food Chem. Toxicol. 2013, 62, 699-706. [CrossRef] [PubMed]

63. McCubrey, J.A.; Steelman, L.S.; Chappell, W.H.; et al. Roles of the Raf/MEK/ERK pathway in cell growth, malignant transformation and drug resistance. Biochim. Biophys. Acta Mol. Cell Res. 2007, 1773, 1263-1284. [CrossRef] [PubMed]

64. McCubrey, J.A.; Steelman, L.S.; Franklin, R.A.; Abrams, S.L.; Chappell, W.H.; Wong, E.W.T.; Lehmann, B.D.; Terrian, D.M.; Basecke, J.; Stivala, F. Targeting the RAF/MEK/ERK, PI3K/AKT and P53 pathways in hematopoietic drug resistance. Adv. Enzyme Regul. 2007, 47, 64-103. [CrossRef] [PubMed]

65. Turpaev, K.T. Role of transcription factor AP-1 in integration of cellular signalling systems. Mol. Biol. 2006, 40, 945-961. [CrossRef]

66. Karpeta, A.; Maniecka, A.; Gregoraszczuk, E.Ł. Different mechanisms of action of 2,2' $2^{\prime}$, $4^{\prime}$-tetrabromodiphenyl ether (BDE-47) and its metabolites (5-OH-BDE-47 and 6-OH-BDE-47) on cell proliferation in OVCAR-3 ovarian cancer cells and MCF-7 breast cancer cells. J. Appl. Toxicol. 2016, 36, 1558-1567. [CrossRef] [PubMed]

67. Fan, C.-Y.; Besas, J.; Kodavanti, P.R.S. Changes in mitogen-activated protein kinase in cerebellar granule neurons by polybrominated diphenyl ethers and polychlorinated biphenyls. Toxicol. Appl. Pharmacol. 2010, 245, 1-8. [CrossRef]

68. Pang, Y.; Qi, G.; Jiang, S. 1,2-Dichloroethane induced hepatotoxicity and apoptosis by inhibition of ERK 1/2 pathways. Can. J. Physiol. Pharmacol. 2018, 96, 1119-1126. [CrossRef]

69. Koinzer, S.; Reinecke, K.; Herdegen, T. Oxidative stress induces biphasic ERK1 / 2 activation in the RPE with distinct effects on cell survival at early and late activation. Curr. Eye Res. 2014, 40, 853-857. [CrossRef]

70. Shen, Z.; Liang, X.; Rogers, C.Q.; Rideout, D.; You, M. Involvement of adiponectin-SIRT1-AMPK signaling in the protective action of rosiglitazone against alcoholic fatty liver in mice. Am. J. Physiol. Liver Physiol. 2010, 298, 364-374. [CrossRef]

71. Pazin, M.; Pereira, L.C.; Dorta, D.J. Toxicity of brominated flame retardants, BDE-47 and BDE-99 stems from impaired mitochondrial bioenergetics. Toxicol. Mech. Methods. 2015, 25, 34-41. [CrossRef] [PubMed]

72. Sciacovelli, M.; Gaude, E.; Hilvo, M.; Frezza, C. The metabolic alterations of cancer cells. Methods Enzymol. 2014, 542, 1-23. [CrossRef] [PubMed]

73. Li, W.; Saud, S.M.; Young, M.R.; Chen, G.; Hua, B. Targeting AMPK for cancer prevention and treatment. Oncotarget 2015, 6, 7365-7378. [CrossRef]

74. Wang, Y.; Yang, J.; Yang, K. The biphasic redox sensing of SENP3 accounts for the HIF-1 transcriptional activity shift by oxidative stress. Acta Pharmacol. Sin. 2012, 33, 953-963. [CrossRef] [PubMed]

75. Jung, S.N.; Yang, W.K.; Kim, J. Reactive oxygen species stabilize hypoxia-inducible factor-1 alpha protein and stimulate transcriptional activity via AMP-activated protein kinase in DU145 human prostate cancer cells. Carcinogenesis 2008, 29, 713-721. [CrossRef] [PubMed]

76. Li, X.; Wang, H.; Wang, J. Emodin enhances cisplatin-induced cytotoxicity in human bladder cancer cells through ROS elevation and MRP1 downregulation. BMC Cancer 2016, 16, 578. [CrossRef] [PubMed]

77. Han, Y.; Wang, Q.; Song, P.; Zhu, Y.; Zou, M.-H. Redox regulation of the AMP-activated protein kinase. PLoS ONE 2010, 5, 15420. [CrossRef] [PubMed]

78. Regoli, F.; Giuliani, M.E. Oxidative pathways of chemical toxicity and oxidative stress biomarkers in marine organisms. Mar. Environ. Res. 2014, 93, 106-117. [CrossRef] [PubMed] 
79. Marsh, G.; Stenutz, R.; Bergman, Å. Synthesis of hydroxylated and methoxylated polybrominated diphenyl ethers-Natural products and potential polybrominated diphenyl ether metabolites. Eur. J. Org. Chem. 2003, 2003, 2566-2576. [CrossRef]

80. Ding, J.; Long, G.; Luo, Y.; Sun, R.; Chen, M.; Li, Y.; Zhou, Y.; Xu, X.; Xao, W. Formation of 1,3,8tribromodibenzo-p-dioxin and 2,4,6,8-tetrabromodibenzofuran in the oxidation of synthetic hydroxylated polybrominated diphenyl ethers by iron and manganese oxides under dry conditions. Environ. Sci. Pollut. Res. 2018, 25, 30160-30169. [CrossRef]

81. Chan, W.K.; Yao, G.; Gu, Y.Z. Cross-talk between the aryl hydrocarbon receptor and hypoxia inducible factor signaling pathways. Demonstration of competition and compensation. J. Biol. Chem. 1999, 274, 12115-12123. [CrossRef] [PubMed]

82. Matikainen, T.; Perez, G.I.; Jurisicova, A.; Pru, J.K.; Schlezinger, J.J.; Ryu, H.-Y.; Laine, J.; Sakai, T.; Korsmeyer, S.J.; Casper, R.F.; et al. Aromatic hydrocarbon receptor-driven Bax gene expression is required for premature ovarian failure caused by biohazardous environmental chemicals. Nat. Genet. 2001, 28, 355-360. [CrossRef] [PubMed]

83. Nie, M.; Blankenship, A.L.; Giesy, J.P. Interactions between aryl hydrocarbon receptor (AhR) and hypoxia signaling pathways. Environ. Toxicol. Pharmacol. 2001, 10, 17-27. [CrossRef]

84. Huang, Y.; Li, W.; Su, Z. The complexity of the Nrf2 pathway: Beyond the antioxidant response. J. Nutr. Biochem. 2015, 26, 1401-1413. [CrossRef] [PubMed]

85. Shan, Q.; Zhuang, J.; Zheng, G.; Zhang, Z.; Zhang, Y.; Lu, J.; Zheng, Y. Troxerutin reduces kidney damage against BDE-47-induced apoptosis via inhibiting NOX2 activity and increasing Nrf2 activity. Oxid. Med. Cell. Longev. 2017, 2017, 6034692. [CrossRef] [PubMed]

86. Park, H.R.; Loch-Caruso, R. Protective effect of nuclear factor E2-related factor 2 on inflammatory cytokine response to brominated diphenyl ether-47 in the HTR-8/SVneo human first trimester extravillous trophoblast cell line. Toxicol. Appl. Pharmacol. 2014, 281, 67-77. [CrossRef] [PubMed]

(C) 2019 by the authors. Licensee MDPI, Basel, Switzerland. This article is an open access article distributed under the terms and conditions of the Creative Commons Attribution (CC BY) license (http:/ / creativecommons.org/licenses/by/4.0/). 